\title{
Servitization of the Manufacturer's Value Chain
}

\author{
David Opresnik, Christian Zanetti, and Marco Taisch \\ Department of Management, Economics and Industrial Engineering, Politecnico di Milano, \\ Piazza Leonardo Da Vinci 32, 20133, Milano, Italy \\ \{david.opresnik, cristiano.zanetti, marco.taisch\}@polimi.it
}

\begin{abstract}
Servitization, the offering of product-services, is a more and more pervasive concept. When applied correctly, it exploits the product and generates additional added value for the manufacturer as for the customer. Until now, servitization has been applied only onto the usage phase of the product, creating services around it. However the product is not the only valuable and tradable asset in a manufacturing enterprise. Therefore this article scrutinizes the possibility to additionally exploit the manufacturer's value chain, by servitizing its components and hence transforming them into products per se. To test this possibility Thoben's seminal representation of servitization was taken and applied onto the components of the value chain identified by Porter. It was elucidated that the proposed concept is feasible and under certain circumstances, it increases the seller's and buyer's sustainable competitive advantage. The article concludes by questioning the effect of this novel concept onto sustainability.
\end{abstract}

Keywords: servitization, value chain, manufacturing, competitive advantage.

\section{Introduction}

Fordism was a time where a mass production represented the core of the benefit. Though, evidently a manufacturing industry as part of the globalisation race with unscrupulous economic, trade and labour policies, indirectly fostering quickly commoditized products, is not a long term solution for developed economies. Hence, out of flexible manufacturing systems, marketing related customer orientations stemmed out the nimble concept of creating product-services from the consumers' products. With this approach manufacturers are trying to achieve and especially sustain their competitive advantage. Strategic management literature is referring to this concept as the sustained competitive advantage, which can lead to sustainability.

Through service oriented approaches, like servitization and Product-Service Systems (PSS), manufacturers tend to create more added value for their customers, as also for themselves in form of higher revenues, prolonged product life cycle, customer loyalty, new customer segments and foremost higher level of competitive advantage. Also due to the increase of services and other fuzzy elements like service level agreements, network collaboration, the imitation and replication of such business models becomes more challenging for competitors. Consequently, not only that servitization increases a manufacturer's competitive advantage, but it also increases 
its retention level, making it more sustainable. Hence, servitization, by increasing the level of exploitation of the product, can be defined as a process that enables the creation of additional substantial added value for the provider as also for the consumer.

However until now the process of servitization has been applied only onto the usage phase of the product (e.g. services for remote machine maintenance, offering an airplane machine per miles, "pay per-view or per-use models" etc. - all services are related to the usage phase). Be that as it may, the end product is not the only valuable and tradable asset in manufacturing enterprises, where each of them has its own personalized value chain [1], with its own strengths and weaknesses, with its own resources, ranging from advanced IT tools to active global collaborative networks. Therefore, this article proposes to apply the concept of servitization to components of the manufacturer's value chain. This means that a manufacturer offers its components, with high added value, to other business entities, as a service. Such offering can be called Value Chain as a Service. Consequently, this article proposes to enable manufacturers to additionally exploit their existing resources along the value chain with the objective to increase its level of competitiveness and leading him one step closer to a more sustainable competitive advantage than its competitors. This article links the pervasive concept of servitization with the concept of the manufacturer's value chain, whereas its components through servitization, become new products or product-services per se.

\section{Research Approach}

In order to avoid the pervasive "paradigm mentality" simultaneously proliferating and polarizing perspectives, which often inhibits discourse across paradigms, biasing theorists against opposing explanation and fostering development of provincial theories [2], this article applies the concept of metatriangulation. It implies a multiperspective view, though not across methods within a single theory or paradigm, but across different theories and paradigms [3]. The intent is to identify differences, tensions as also similarities, hence increase reliability of findings. Hence it draws from two research fields, first from the field encompassing service oriented approaches, like servitization, PSS, servicizing etc. and secondly, from the field of strategic management, encompassing the concepts of competitive advantage arising from different schools, the concept of coopetition and understandingly the value chain concept. The test of servitizing the value chain will be performed in the field of service oriented approaches, whereas the reliability of the results will be analyzed through the concepts of strategic management, with the clear objective to unravel opportunities, but foremost inconsistencies and tensions in the scrutinized concept. Such rest of robustness of the findings substantially increases their level of reliability.

\section{Relation to Existing Work}

\subsection{Strategic Management}

Competitive advantage of a manufacturing enterprise is a dependent research variable, which is affected, by applying servitization to the usage phase of the product or 
potentially to a value chain. Therefore, the most prevailing views are depicted in the continuation. Porter [4] defines two main determinants for relative performance: a) the operational effectiveness and $b$ ) the choice of strategic positioning or simply the choice of strategy. The latter defines which activities to perform and in what combinations [5], thus it is not just a list of individual activities. Meanwhile operational effectiveness defines how efficiently those activities are performed. If commencing with the view where the business environments has most influence, the next prevailing view arises from the behavioural school, where one of its most visible representative is Mitzberg [6]. It is characteristic for this view, that the enterprises will be able to develop their own environment, meaning that they can create new non-existing needs, enter new markets, but of course all this at the price of potential failure. In this category fits also Schumpeter's view, especially on the role of the entrepreneur as the prime cause for economic development, hence implying that he creates new markets and offerings and is not defined by the environment. Lastly the Resource Based View [7] focuses on the resources and their bundles of the enterprise based on which competitive advantage is achieved and sustained.

Coopetition is depicted, as it can be one of the potential results of servitizing the value chain. It argues that one single relationship can comprise of both cooperation and competition and those two enterprises can compete and cooperate simultaneously. The concept can be described in a wider context by Nalebuff and Brandenburger [8], where two enterprises cooperate with different products (e.g. sportswear and healthy food) [8]. Though, there also exists a more focused view on coopetition taken up by Bengtsson \& Kock [9], where two enterprises compete on the end user's market, but cooperate in activities along the value chain (e.g. two breweries compete in selling bier, but cooperate in dealing with empty bottles).

Value Chain is introduced as the concept to where servitization could be applied. Therefore, its definition must be clear. Many concepts have been developed since its conception, like value constellation, but this article goes to the root and therefore uses Porter's [1] definition. Value chain analysis describes the activities within and around an organization, and relates them to an analysis of the competitive strength of the organization. He distinguishes two main areas. The first is the primary set of activities and is directly concerned with the creation or delivery of a product or service, being logistics, operations, marketing and sales and service. The second set of activities represent the support activities (human resources, technology, infrastructure, procurement), which are linked to the primary ones helping them to improve their effectiveness or efficiency. Lastly, it must be emphasized that it is considered that the competences needed to design and manage a value chain, which designs and offers a $\mathrm{P}-\mathrm{S}$, are included in the value chain.

\subsection{Service Oriented Approaches in Manufacturing}

At least two main types of service oriented approaches exist in literature. In 1988 the definition of servitization was coined by Vandermerwe and Rada [10], which defined it as "market packages or bundles of customer-focused combinations of goods, services, support, self-service and knowledge". The other mainstream is called the PSS. 
It is a Scandinavian concept offering a promising avenue to achieve sustainable consumption and production patterns and to improve the competitiveness of industrial manufacturers [11], [12]. The adoption of a PSS involves an orientation toward selling a product's functionality instead of selling the product itself. It is defined as "integrated offerings of products and services that deliver value in use" [13]. Of course there also exists other definitions, such as from Ren and Gregory [14] stating that servitization is "a change process wherein manufacturing companies embrace service orientation with the aim to satisfy customer's needs, achieve competitive advantages". Other concepts are servicizing [15], functional sales [16] or even full-service contracts [17] and also Industrial PSS [18]. Lastly, Baines [13] has proposed that PSS becomes a subset of servitization, concluding that servitization is the widest term used in the service oriented strategies.

Thoben's classical representation of servitization [19] provides benefits to the customers of the P-S, hence the benefits of servitization are generated during the P-S usage phase. Its first level deals with the pure product, the second level includes services that support the product and can already generate revenues (e.g. warranty, maintenance). The third level adds services that differentiate the product (e.g. Hilti International's ,pay per hole model“ [20]). Lastly, the forth level predicts that the product is still present, though remains in the ownership of the manufacturer and the revenues are generated by the services, selling the functionality (e.g. the manufacturer sells a constant temperature in a specific place and not the heating system). This is the highest level of servitization that can be found in literature.

\subsection{Hypotheses Development}

All the above mentioned forms of service oriented approaches have in common at least one characteristic; they are all applied onto the usage phase of the product or put differently, the benefits of the service oriented approaches are intended for consumers using the product. As servitization is a process of adding or generating additional value for all involved parties, the article thereby endeavours to fill this gap and to extend the application of servitization throughout the manufacturer's value chain. This would enable practitioners to substantially increase the exploitation level of their value chain and to increase their competitive advantage. As for scholars, they will be able to expand the limits of the applicability of servitization.

As already indicated, the two hypotheses are developed out of two essential fields for testing the possibility to servitize a manufacturer's value chain. Servitization as the widest concept was used, where Thoben's representation of servitization is widely used. Therefore, by taking the highest concept in service oriented approaches and a widely recognized representation of servitization, it is considered satisfactory that Thoben's representation is used to test the applicability of servitization onto components of a manufacturer's value chain. Consequently the following hypothesis arises: "Can Thoben's representation of servitization levels [19] be applied onto a component of a value chain, which consequently becomes servitized?" The next hypothesis assays two matters; first, the impact of servitizing its own value chain on the level of competitive advantage and the second, the effect on the buyer's competitive advantage of acquiring 
such a value chain component. Hence the second hypothesis is the following: "Servitizing the value chain of a manufacturer has a positive impact on its level of competitive advantage and its sustainability as also on the buyer's competitive advantage."

\section{$4 \quad$ Findings}

This section presents the findings of applying the concept of servitization using Thoben's representation, onto the components of the value chain. In order to perform the test, if servitization is applicable onto the value chain, two activities from the primary set (operations and sales) and two activities from the secondary set (technology and human resources) of activities from Porter's value chain [1] were chosen to be applied onto Thoben's four servitiztion levels. The first chosen activity from Porter's secondary set of value chain activities is Technology, where the Product (first level) can be an existing software (SW) for product personalization owned by the manufacturer. In the second servitization level supporting services are added to the product, like maintenance and partial modularization. In the third level, where the Product is differentiated with services, the SW with existing maintenance services can be leased. Finally, the highest level, being Product as a service, only the functionality of the output is sold; in this case the buyer pays only for the functionality delivered by the SW and its related services. The second component of the value chain, deriving also from the supporting set of Porter activities, is Human Resources. This value's chain component is special, because it is needed in order to servitize all other parts of the value chain. Therefore, this component is servitized through the servitization of other components (e.g. the competency of SW development is be sold through the servitization of the $\mathrm{SW}$ ). The third component is Operations, arising from the primary set of Porter's value chain activities. For this activity, the example for the Product, the first servitization level, is the setting up of a flexible manufacturing network supporting the provision of a servitized product. Interestingly the product in this level is a service. In the next serivtization level, additional basic services are added, like maintenance and additional modularisation or its optimization. In the third level of servitization, where services differentiating the product are introduced; hence, the flexible manufacturing network is not sold anymore, but its usage is sold, like the model "pay per use". The buyer does not own the network and pays only for its usage. The forth level indicates that the buyer pays only for the output or the functionality provided by such network. The forth component of the value chain to be tested is Sales, arising from the primary set of activities. The product in the first level of servitization can be the setting up of sales network, which again interestingly is not a product per se. In the second level, basic services are added, like sales network optimization. In the third level, only the usage of the sales network is sold, which can reflect the usage of sales network, where the payment is effectuated by the actual sale. The forth servitization level, where the product is offered as a service, can be for example the functionality of generating a certain profit, regardless of the basic product, which is the sales network.

After exemplifying the servitization of different components of Porter's value chain, it is evident that servitization is applicable onto the value chain. Furthermore, 
the core product around which servitization revolves, is not necessarily always a pure product, but can be a pure service, constituted from formalized relations with different manufacturers with a set of predefined business terms (price, flexible delivery ...), which is also called a manufacturing network or even an ecosystem.

\subsection{Guidelines for Servitizing the Value Chain}

The manufacturer has to identify first which of the activities in the value chain are the most different and effective [5]. Secondly, one should identify what is the nucleus of its competitive advantage and decide what is to be protected. Then the manufacturer can offer: a) classical, but valuable parts of its value chain (e.g. access and sales network) and/or b) components of the value chain that were the most affected by the servitization; those are usually the one that maximizes flexibility, personalization and customization of P-S. The latter are especially interesting for manufacturers wanting to servitize their business with lesser risk, almost "on the fly". In addition, servitization is a more and more pervasive trend, meaning that the demand for components of the value chain fitted for P-S generating and/or delivering will be on the rise.

\section{Discussion}

The benefits of servitizing value chain components are depicted from two points of views, the seller's, which is the manufacturer, and from the buyer's. The seller can generate additional income, by increasing the exploitation level of its existing resources. This means that additional products or P-S are created, thus enlarging its portfolio. Furthermore, if the manufacturer is on a B2C market, it enables him to enter into a B2B market. Lastly, if the manufacturer is already present on the B2B market with a non-servitized product (e.g. manufacturer of fuel pumps), such seller has the opportunity to servitize its business; though not its end product, but different components of its value chain. This can increase the manufacturer's competitive advantage. However, if a component of the value chain is sold, from which the core of the strategy is duplicable, this can have negative consequences. To alleviate such risk, the manufacturer must master its strategy and be able to recognize its core strengths and weaknesses. Finally, the proposed strategy is harder for competitors to imitate and replicate and secondly it decreases the need to sell its products on a mass scale on a lower price, as additional revenues are generated through servitizing the value chain. Such behaviour could help substantially lead a manufacturer to sustainability.

In the previous paragraph, the effect of selling the value chain components was analyzed. In the current one, the effect of buying the value chain component is discussed. It increases its competitive advantage due to the capability of faster entrance into new markets or market segments; for instance it opens up the possibility to swiftly servitize its business, especially as literature and practitioners are still on the search for numerous methods and tools for easier servitization of the end product. Also as already known, servitization can represent an additional stable income stream. Besides, the buyer is acquiring components of the value chain that are not 
characteristics of the usual set of internal resources, which means that such business is becoming harder to imitate and replicate. However, if the buyer is not conscious enough regarding the concept of the strategic fit, a wrong buy can be made, which will decrease its competitive advantage. Therefore, before the acquisition, the buyer must perform a strategic fit of the new component with its current strategy (e.g. one acquires the usage of a flexible manufacturing ecosystem, which generates only expensive, high-end products, but the current customer base of the buyer appreciates only low-priced products). Anyhow, buying a component of the value chain with high added value enables the buyer to quickly enhance its competitive position and to retain it due to the higher level of complexity of its strategy.

It can be concluded that the first hypothesis can be fully accepted, as servitization, as presented by Thoben [19], can be applied to the components of the manufacturer's value chain. As for the second hypothesis, it can be concluded that the seller and buyer increase their level of competitive advantage as also its capability to reach sustainability. However, this is feasible only under the following two sets of conditions: first, both parties must be highly conscious of their strategy, their strengths and weaknesses and secondly, they must possess an understanding of the strategic fit between the component of the value chain and their internal strategy. Though, the limitation of this article is quite obvious, as it has not yet been tested on multiple use cases.

\section{Conclusion}

As literature still struggles with the problem of how to create and offer P-S, some manufacturers have already succeeded in doing so. Through servitizing their products, their value chains are fitted to generate and deliver innovative P-S. Those components can be offered to other manufacturers so they can servitize their product as well. Namely, the effect of servitization is not only the servitized product, but also a more customized, flexible, efficient, technologically advanced and efficient value chain that can become a new product or product as a service per se. Furthermore manufacturers positioned in the middle of the value chain (e.g. car fuel pumps manufacturers) can now apply the concept of servitization, though not on their end product, but onto their value chain. The presented concept opens up a new palette of opportunities, but also unknowns. One of them to be tackled, is to assay, if servitization of the value chain can underpin the current business models that are based on the idea to sell as much products as possible, hence not being adequate in terms of sustainability and must be carefully revised [21].

\section{References}

[1] Porter, M.E.: Competitive advantage: Creating and sustaining superior performance. Free Press, New York (1985)

[2] Lewis, M.W., Grimes, A.I.: Metatriangulation: Building theory from multiple paradigms. Academy of Management Review 24(4), 672-690 (1999) 
[3] Gioia, D.A., Pitre, E.: Multiparadigm perspectives on theory building. Academy of Management Review, 584-602 (1990)

[4] Porter, M.E., Kramer, M.R.: The competitive advantage of corporate philanthropy. Harvard Business Review 80(12), 56-68 (2002)

[5] Porter, M.E.: What is strategy? Published (November 1996)

[6] Mintzberg, H.: The strategy concept 1: five p's for strategy. U. of California (1987)

[7] Peteraf, M.A.: The cornerstones of competitive advantage: a resource-based view. Strategic Management Journal 14(3), 179-191 (1993)

[8] Nalebuff, B.J., Brandenburger, A.: Co-opetition. Harper Collins Business (1996)

[9] Bengtsson, M., Kock, S.: "Coopetition" in Business Networks-to Cooperate and Compete Simultaneously. Industrial Marketing Management 29(5), 411-426 (2000)

[10] Vandermerwe, S., Rada, J.: Servitization of business: Adding value by adding services. European Management Journal 6(4), 314-324 (1988)

[11] Tukker, A., Tischner, U.: Product-services as a research field: past, present and future. Reflections from a decade of research. Journal of Cleaner Production 14(17), 1552-1556 (2006)

[12] Tukker, A.: Eight types of product-service system: eight ways to sustainability? Business Strategy and the Environment 13(4), 246-260 (2004)

[13] Baines, T.S., Lightfoot, H.W., Benedettini, O., Kay, J.M.: The servitization of manufacturing: a review of literature and reflection on future challenges. Journal of Manufacturing Technology Management 20(5), 547-567 (2009)

[14] Ren, G., Gregory, M.: Servitization in manufacturing companies. Presented at the 16th Frontiers in Service Conference, San Francisco, CA (2007)

[15] Rothenberg, S.: Sustainability Through Servicizing. MIT SLoan Management Review 48(2), 83-89 (2007)

[16] Markeset, T., Kumar, U.: Product support strategy: conventional vs. functional products. Journal of Quality in Maintenance Engineering 11(1), 53-67 (2005)

[17] Stremersch, S., Wuyts, S., Frambach, R.T.: The Purchasing of Full-Service Contracts. Industrial Marketing Management 30(1), 1-12 (2001)

[18] Meier, H., Roy, R., Seliger, G.: Industrial Product-Service Systems-IPS2. CIRP Annals - Manufacturing Technology 59(2), 607-627 (2010)

[19] Thoben, K.-D., Eschenbächer, J., Jagdev, H.: Extended products: evolving traditional product concepts. In: 7th international Conference on Concurrent Enterprising, Bremen (2001)

[20] Reinartz, W., Ulaga, W.: How to Sell Services More Profitably. Harvard Business Review, 91-96 (May 2008)

[21] Garetti, M., Taisch, M.: Sustainable manufacturing: trends and research challenges. Production Planning \& Control 23(2-3), 83-104 (2012) 